\title{
Vatandaşlık Algısı Ölçeği'nin Geçerlik ve Güvenirlik Çalışması
}

DOI: 10.26466/opus.938404

\author{
Mehmet Sabir Çevik * - Şefika Şule Erçetin ** \\ * Dr. Öğr., Hacettepe Üniversitesi, Eğitim Yönetimi Ana Bilim Dalı, Ankara/Türkiye \\ E-Posta: sahici1980@gmail.com \\ ORCID: $\quad$ 0000-0002-8817-4747 \\ ** Prof. Dr., Hacettepe Üniversite, Eğitim Yönetimi Ana Bilim Dalı, Ankara/Türkiye \\ E-Posta: sefikasule@gmail.com \\ ORCID: $\quad \underline{0000-0002-7686-4863}$
}

Öz

$\mathrm{Bu}$ araştırmanın amacı ortaöğretim (lise) kurumu öğrencilerinin vatandaşlık algılarını ölçebilecek geçerli ve güvenir likert tipi bir ölçme aracı geliştirmektir. Araştırmanın çalışma grubu 2020-2021 eğitim-öğretim yılında Siirt il merkezinde ortä̈ğretim kurumlarında öğrenim gören öğrencilerden oluşmaktadır. Araştırmanın açımlayıcı faktör analizi bulguları 485, doğrulayıcı faktör analizi bulguları ise 426 öğrenci üzerinden elde edilmiştir. Açımlayıcı faktör analizi sonuçlarına göre ölçek, 28 madde ve 5 alt boyuttan oluşmuştur. Bu alt boyutlar; insan olmak, görev ve sorumluluk, hak ve özgürlükler, etkin (aktif) vatandaşlık ve birlikte yaşama şeklinde adlandırılmıştır. Ölçeğin açımlayıcı faktör analizi sonucunda ortaya çıkan faktöryel yapının doğrulanıp doğrulanmadığım tespit etmek amacıyla birinci düzey faktör analizi ve ikinci düzey doğrulayıcı faktör analizi yapılmıştır. Birinci düzey faktör analizi ve ikinci düzey doğrulayıcı faktör analizi sonuçları ölçeğin faktör yapısının verilerle uyum içinde olduğuna işaret etmiştir. Ölçeğin Cronbach's Alpha iç tutarlık katsayısı .90, Spearman Brown iki yar güvenirlik katsayısı ise .84 olarak hesaplanmıştır. Bu bağlamda "Vatandaşlık Algısı Ölçeğinin (VAÖ)" psikometrik açıdan öğrencilerin vatandaşlık algıların ölçebilecek geçerli ve güvenilir bir ölçme aracı olduğu sonucuna ulaşılmıştır.

Anahtar Kelimeler: Vatandaşlık, Vatandaşlık Alg̨ısı, Ortaöğretim (Lise) Öğrencileri. 


\title{
Validity and Reliability Study of the Citizenship Perception Scale
}

\begin{abstract}
$*$
Abstract

The aim of this study is to develop a valid and reliable Likert type measurement tool that can measure the citizenship perceptions of secondary education (high school) students. The study group of the research consists of students studying at secondary education institutions in the city center of Siirt in the 2020-2021 academic year. The exploratory factor analysis findings of the study were obtained from 485 students, and the confirmatory factor analysis findings were obtained from 426 students. According to the exploratory factor analysis results, the scale consists of 28 items and 5 subdimensions. These sub dimensions have been named as being human, duty and responsibility, rights and freedoms, active citizenship and coexistence. First-order confirmatory factor analysis was conducted to determine whether the factorial structure of the scale was confirmed as a result of the exploratory factor analysis. The first level confirmatory factor analysis results indicated that the factor structure of the scale is in agreement with the data. The Cronbach Alpha internal consistency coefficient of the scale was calculated as .90, and Spearman Brown split-half reliability coefficient was calculated as .84. In this context, it was concluded that the "Citizenship Perception Scale (CPS)" is a valid and reliable measurement tool that can measure students' perception of citizenship psychometrically.
\end{abstract}

Key Words: Citizenship, Perception of Citizenship, Secondary Education (High School) Students. 


\section{Giriş}

Modern devletlerin doğuşuyla birlikte olgunlaşmaya ve ortaya çıkmaya başlayan vatandaşlık kavramı, köken olarak oldukça eski bir geçmişe sahiptir. Vatandaşlığa ilişkin tanımlamalar, Antik Yunan medeniyetinden başlayarak günümüze kadar kültürel, sosyal ve coğrafik faktörlerin etkisiyle sürekli bir değişim geçirmiştir (Gündüz ve Gündüz, 2007; İbrahimoğlu, 2014). Pamuk'a (2007) göre vatandaşlık, doğumla birlikte elde edilen ve bir devletin vatandaşını başka devletlerin vatandaşlarından ayıran özellikler, Waltzer ve Heilman'a (2005) göre vatandaşlık bir siyasi otoriteye bağlı olan tüm bireylerin her açıdan eşit haklara sahip olması, Erdem'e (2012) göre vatandaşlık aynı toprak parçası üzerinde yaşayan bireylere verilmiş hukuki statü, Marshall ve Bototomore'ye (2000) göre vatandaşlık bir toplumun tüm üyelerine tanınan sosyal statü olarak tanımlanmaktadır Alanyazınında vatandaşlığa ilişkin farklı tanımlamalar olsa da vatandaşlı̆̆ın genel olarak birey ve devlet arasında meydana gelen siyasi bağ olarak ifade edildiği (Battery, 2003; Edge ve Copp, 2000; İbrahimoğlu, 2014) söylenebilir.

Tarihsel süreç içersinde vatandaşlık, çeşitli modeller şeklinde ele alınmıştır. Örneğin; liberal model vatandaşlık bireyselliğe ve bireysel kimliğe; topluluk modelinde vatandaşlık ulusal ve kültürel kimliğe; demokratik modelde vatandaşlık vatandaş olma özelliğine önem verir (Kartal, 2002). Çoğu düşünür ise vatandaşlığı sivil, siyasal ve toplumsal boyutlarla ele almaktadır (Biesta, 2014; Wildemeersch, 2014). Sivil vatandaşlık bireylerin sahip olması gereken temel hak ve özgürlüklere, siyasal vatandaşlık seçme-seçilme ve siyasi bir örgütlenmeye katılım hakkı, toplumsal vatandaşlık ortak amaçlar çerçevesinde bireylerin birlikte hareket etmesine vurgu yapmaktadır (Biesta, 2014; Marshall, 2016). Tüm bu açiklamalardan hareketle vatandaşlığın teorik alt yapısının ya da kuramsal bileşenlerinin "insan olmak, hak ve özgürlükler, görev ve sorumluluklar, etkin (aktif) vatandaşlık ve birlikte yaşama (çokkültürlülük / çeşitliliğe çoğulcu bakış)" boyutlarıyla ilişkili olduğu anlaşılmaktadır.

Vatandaşlı̆̆ın "insan olmak" boyutunda her insan değerlidir yaklaşımı hâkimdir. Başka bir ifadeyle vatandaşlığın insan olmak 
boyutu, insana insan olması nedeniyle önem vermeyi ve insan olma değerini her türlü değerden üstün tutmayı içermektedir. İnsan olmak boyutunda kişisel farklılıklar bir kenara bırakılarak insanlar arasında dil, din, kültür ve ırk farkı gözetilmez (Flowers, 2000). Hak ve özgürlükler boyutu; bireylere hukuk düzeni tarafından verilen yetkiler ile bireylerin bir baskı ve kısıtlama olmaksızın herhangi bir konuda kendi iradelerine göre karar vermeleridir (Esen, 2011; Yurtseven, 2006). Hak ve özgürlükler bireylere sınırsız ve orantısız bir serbestlik tanımaz, aksine vatandaşlara bazı sorumluluklar yükler (Yeşil, 2002). Temel hak ve özgürlükler kişisel hak ve özgürlükler, sosyal-ekonomik hak ve özgürlükler, siyasal hak ve özgürlüklerden meydana gelmektedir. Görev ve sorumluluk boyutu; vatandaş olmanın bir gereği olarak bireylerden beklenen görev ve sorumlukların yerine getirilmesidir. Görev ve sorumluluk sahibi vatandaş, toplumsal prensiplere ve kanunlara uygu hareket eder (Westheimer, 2015). Devletlerin gelişmişlik düzeyi ve çeşitli gereksinimlerine göre vatandaşlarından görev ve sorumluluk kapsamındaki beklentileri değişiklik gösterebilir. Türkiye açısından devletin kendi vatandaşlarından görev ve sorumluluk kapsamındaki belli başlı beklentileri oy kullanmak, vergi ödemek, yasalara uymak ve askere gitmek şeklinde özetlenebilir (Şahin, 2012). Etkin (aktif) vatandaşlık boyutu ise demokrasi ve insan haklarına uygun olarak bireylerin herhangi bir baskı altında bulunmaksızın hür iradeleriyle siyasi yaşama katılımlarıdır (Golubeva, 2018). Ersoy (2007) etkin (aktif) vatandaşlı̆̆ın seçimlerde oy kullanma, güncel sosyal taleplere duyarlı olma ve herhangi bir siyasi örgütlenmede yer alabilme özgürlügüyle ilgili olduğunu ifade etmektedir. Etkin (aktif) vatandaş toplumsal olayların gidişatına karşı tepkisiz kalmaz, farklı ve etkin yollarla toplumsal olayları şekillendirmeye çalışır (Ross, 2012; Onyx, Kenny ve Brown, 2012). Son olarak vatandaşlığın birlikte yaşama (çokkültürlülük / çeşitliliğe çoğulcu bakış) boyutu; bir arada olmanın, farklı değerlere sayg1 duymanın ve farklılıklara dayanan siyasi oluşumların desteklenmesine vurgu yapar (Parekh, 2002). Birlikte yaşama kültüründe toplumun genel değerleriyle ters düşmeyen her türlü düşünme ve örgütlenme serbesttir (Demir ve Acar, 2005). Birlikte yaşama felsefesinde yaşamın etnik köken, din, dil, ırk ve renk gibi hiçbir farklılık yadsınmaz, aksine bir zenginlik olarak görülür (Fay, 2017). Dolayısıyla vatandaşlık 
algısının tüm bu boyutları içine alan geniş bir kavram olduğu söylenebilir.

Vatandaş olma bilinci ve vatandaşlık algısı vatandaşın devletten beklentileri ile devletin vatandaştan beklentileri bakımından önemlidir. Çünkü vatandaşlık algısı, içinde bulunulan toplumun genel kabullerinin yeni nesillere aktarımda ve beraber yaşama anlayışının yerleşmesinde belirleyici olabilmektedir. Aynı zamanda vatandaşlık algısı, milli kimlik algısının şekillenmesinde de büyük bir rol oynamaktadır (İpek, 2011; Osler ve Starkey, 2003). Bu nedenle tarih boyunca bireylerin vatandaşlik algıları hem politik hem de toplumsal açılardan ele alınmıştır (Blaug ve Schwarzmantel, 2016; Marshall, 2016). Bireyin hak ve özgürlükler çerçevesinde siyasi süreçlere etkin katılımı vatandaşlığın politik; bireyin toplumsal kurallara ve yapıya uygun hareket etmesi ise vatandaşlığın toplumsal özelliklerine işaret etmektedir (Biesta, 2014). Vatandaşlık algısı politik ve toplumsal yönleriyle dinamik, toplumlara göre değişiklik göstermesi nedeniyle bağlamsal, pek çok özelliği kendi içerisinde barındırması bakımından da çok boyutlu bir kavramdır (Schugurensky, 2005). Vatandaşlık algısına ilişkin tanımlar ve açılamalar ise kavramın çok boyutlu olmasıyla ve hızla değişen dünya düzeninin gereklileriyle izah edilebilir. Bu açıdan bakıldığında vatandaşlık algısına yüklenen anlam ve bireylerden beklenen istendik vatandaşlık algısının zaman zaman değiştiği söylenebilir.

Eğitim sistemleri değişen koşullar içerisinde vatandaşlık görevlerini yerine getirebilen ve vatandaşlığ gerçek anlamda benimsemiş bireyler yetiştirmeyi amaçlar (Öztürk ve Deveci, 2011). Özellikle öğrencilerin sahip olmaları gereken etkin vatandaşlık becerilerinin ve vatandaşlık değerlerinin temel vatandaşlık yeterlikleri arasında görülmesi (Özden, 2011) söz konusu amaca hizmet etmektedir. Nitekim yurt içi (Bingöl, 2000; Çolak, 2015; Demirbaş, 2016; Durmuş, 2017; Durualp ve Doğan, 2017; Ersoy, 2012; İçen, 2017; İçen, Öztürk ve Yılmaz, 2017; Öcal, 2011; Özbek, 2004; Tonga, 2013; Utku, 2015) ve yurt dışı alanyazınında (Dinesen, Norgaard ve Klemmensen, 2014; Evans, 2006; Groot, 2011; Hahn, 2015; Kennedy, 2007; Kuang ve Kenedy, 2014; Marshall, 2005; O'Brien ve Smith, 2011; Losito ve D'Amira, 2003; Sears ve Hughes, 1996; Schulz, Ainley, Fraillon, Kerr ve Losito, 2009; Torney-Purta, Lehmann, Oswald ve Schulz, 1999; Zhang, 2011) vatandaşlık kavramının çeşitli 
yönleriyle ele alınması ve öğrencilerin vatandaşlık algılarının ölçüldüğü çok sayıda araştırmanın varlığı vatandaşlık konusuna verilen önemin bir göstergesi olarak değerlendirilebilir. Öte yandan alanyazınında vatandaşlığa ilişkin bazı araştırmalar, ölçek geliştirme çalışması şeklinde de yapılmıştır (Arslan, 2014; Durualp ve Doğan, 2017; İçen, Öztürk ve Yilmaz, 2017; Kaya, 2013; Morais ve Ogden, 2011; Tonga, 2013; Utku, 2015; Uydaş, 2014). Ancak vatandaşlığa yönelik sözü edilen ölçek geliştirme çalışmaları, öğrencilerin vatandaşlık algılarını bir bütün olarak ölçmemekte veya vatandaşlığın sadece tek boyutu üzerinde yoğunlaşmaktadır. Bu nedenle öğrencilerin vatandaşlık algılarını bir bütünlük içerisinde ölçebilecek ölçme araçlarının geliştirilmesi alanyazındaki boşluğu doldurabilir ve alanyazına katkı sağlayabilir. Ayrıca vatandaşlık algısına yönelik geliştirilecek güncel ve yeni bir ölçme aracının öğrencilerin vatandaşlık algılarının daha iyi anlaşılmasına 1şık tutacağı umut edilmektedir.

Görüldüğü gibi vatandaşlık algısının öğrencilerde hangi düzeyde olduğu, öğrencilerin vatandaşlık algılarının hangi yönde yoğunluk kazandığı ve öğrencilerin istendik vatandaşlık algısına sahip olup olmadıklarının belirlenmesi ancak geçerli ve güvenilir ölçme araçlarıyla mümkündür. Bununla birlikte geçerli ve güvenilir bir ölçme aracının geliştirilmesi öğrencilerin vatandaşlık algılarının tespit edilerek öğrencilerde vatandaşlık davranışlarının tahmin edilmesine de katkı sağlayabilir. Bu doğrultuda mevcut araştırma, öğrencilerin vatandaşlık algılarını ölçebilecek bir ölçme aracı geliştirmeyi amaçlamaktadır. Araştırmada bu temel amacının yanı sıra aşağıda belirtilen sorulara da yanıt aranmaya çalışılmıştır;

1. Vatandaşlık algısı ölçeği, öğrencilerin vatandaşlık algısının ölçülmesinde kullanılabilecek psikometrik açıdan geçerli ve uygun bir ölçek midir?

2. Vatandaşlık algisı ölçeği, araştırmalarda kullanılabilecek güvenilir bir ölçek midir? 


\section{Yöntem}

Araştırmanın bu bölümü araştırma modeli, çalışma grubu, ölçek geliştirme süreci, verilerin toplanması ve verilerin analizi başlıklarından oluşmaktadır.

Araştırma Modeli: $\mathrm{Bu}$ araştırma tarama modelinde nicel bir araştırmadır. Tarama modeli araştırmaları evrenin geneli hakkında bir yargiya varmak amaciyla evrenin tamamı ya da evreni temsil eden örneklem üzerinde yürütülen araştırmalardır (Erçetin ve Açıkalın, 2020; Karasar, 2014). Tarama çalışması olarak yapılan bu araştırma çerçevesinde vatandaşlık algısı ölçeğine ilişkin geçerlik ve güvenirlik çalışmaları yapılmıştır.

Çalışma Grubu: Araştırmanın, açımlayıcı faktör analizi (AFA) ve doğrulayıcı faktör analizi (DFA) için iki çalışma grubu oluşturulmuştur. AFA ve DFA çalışma grubu 2020-2021 eğitim-öğretim yılı Siirt il merkezinde resmi ortaöğretim (lise) kurumlarında öğrenim gören ve araştırmaya gönüllü olarak katılan öğrencilerden oluşmaktadır. Ölçek geliştirme çalışmalarında genellikle 300 kişilik veya ölçek maddelerinin en az beş katı kadar katılımcı sayısı olması yeterli görülmektedir (Comrey ve Lee, 1992; Tabachnick ve Fidell, 2013). Bu bağlamda birinci çalışma grubu AFA için 485 öğrenciden; ikinci çalışma grubu DFA için 426 öğrenciden veri toplanmıştır. Ölçeğin AFA uygulaması için 485, DFA uygulaması için 426 öğrenciye ulaşılmış olması örneklem sayısının oldukça yeterli olduğuna işaret etmektedir. AFA'nın yapıldığı çalışma grubundaki öğrencilerin 250'si (\%51.5) k1z, 235'i (\%48.5) erkek; 139'u (\%28.7) 9.sınıfta, 107'si (\%22.1) 10.sinifta, 147'si (\%30.3) 11.sınıfta, 92'si (\%19) 12.sinıfta; 331'i (\%68.2) anadolu, fen ve sosyal bilimler lisesinde, 154 'ü (\%31.8) ise mesleki ve teknik, imam-hatip ve spor lisesinde öğrenim görmektedir. DFA'nın uygulandığ öğrencilerin 219'u (\%51.4) kız, 207'si (\%48.6) erkek; 125'i (\%29.3) 9.sınıfta, 93'ü (\%21.8) 10.sinıfta, 130'u (\%30.5) 11.sinıfta, 78'si (\%18.3) 12.sınıfta; $289^{\prime}$ u (\%67.8) anadolu, fen ve sosyal bilimler lisesinde, 137'si (\%32.2) ise mesleki ve teknik, imam-hatip ve spor lisesinde öğrenim görmektedir. 
Öçek Geliştirme Süreci: Öğrencilerin vatandaşlık algısını ölçmek amacıyla "Vatandaşlık Algısı Ölçeği (VAÖ)" geliştirilmiştir. VAÖ'nün boyutları ve maddeleri Milli Eğitim Bakanlığı'nın (MEB) Sosyal Bilgiler, İnsan Hakları, Vatandaşlık ve Demokrasi dersleri öğretim programındaki "insan olmak (her insan değerlidir), görev ve sorumluluk, hak ve özgürlükler, etkin (aktif) vatandaşlık, birlikte yaşama (çeşitliliğe çoğulcu bakış)" temaları temel alınarak oluşturulmuştur (Altay vd., 2019; Tüysüz, 2019; Tüzün, 2019). Bununla birlikte madde havuzu oluşturma süreci boyunca vatandaşlıkla ilgili yurt içi (Bingöl, 2000; Çolak, 2015; Demirbaş, 2016; Durmuş, 2017; Durualp ve Doğan, 2017; Ersoy, 2012; İçen, 2017; İçen, Öztürk ve Yılmaz, 2017; Öcal, 2011; Özbek, 2004; Tonga, 2013; Utku, 2015) ve yurt diş1 alanyazını (Dinesen, Norgaard ve Klemmensen, 2014; Evans, 2006; Groot, 2011; Hahn, 2015; Kennedy, 2007; Kuang ve Kenedy, 2014; Marshall, 2005; O'Brien ve Smith, 2011; Losito ve D'Amira, 2003; Sears ve Hughes, 1996; Schulz, Ainley, Fraillon, Kerr ve Losito, 2009; TorneyPurta, Lehmann, Oswald ve Schulz, 1999; Zhang, 2011) ayrıntılı bir şekilde taranmış ve vatandaşlık algısını ölçen benzer ölçekler incelenmiştir. Aynı zamanda 52 öğrenciye vatandaşlık konulu kompozisyonlar da yazdırılmıştır.

Alanyazın taramasından ve kompozisyon yazılarından hareketle 68 maddeden oluşan VAÖ madde havuzu oluşturulmuştur. Dörtlü likert tipinde tasarlanan VAÖ, "1-Kesinlikle katılmıyorum, 2-Katılmıyorum, 3Katılıyorum ve 4-Kesinlikle katılıyorum" aralığında cevaplanmaktadır. Ölçekten tersten kodlanan madde bulunmamaktadır. 68 maddeden oluşan ölçek madde havuzu, kapsam geçerliği bakımından 3'ü eğitim yönetimi, 2'si ölçme ve değerlendirme alanından olmak üzere toplam 5 uzman kişinin görüşüne sunulmuştur. Uzmanlardan gelen dönütler ve öneriler doğrultusunda aynı anlama gelen veya ölçülmek istenilenle ilgili olmayan bazı maddelerin olduğu saptanmıştır. Bu nedenle VAÖ'nün maddeleri bir kez daha gözden geçirilmiş ve gerekli düzenlemeler yapılmıştır. Ayrıca koloyca cevaplandırılabilirlik ve anlaşılabilirlik açısından da uygun olmayan maddelerin olduğu görülmüştür. Bu ölçütler ve özellikler bağlamında madde havuzundan toplam 18 madde çıkartılarak ön uygulamaya hazır 50 maddelik bir ölçek geliştirilmiştir. 50 maddeden oluşan VAÖ taslak ölçek formu 
rastgele Siirt il merkezinde ortaöğretim (lise) kurumlarında öğrenim görev 84 öğrenciye ön pilot çalışma olarak uygulanmıştır. Ön pilot uygulama sonucunda öğrencilerden alınan dönütler doğrultusunda ve uzman görüşleri çerçevesinde taslak ölçek maddeleri yeniden gözden geçirilmiştir. Bu kapsamda ölçekten 6 madde daha çıkartılarak ölçek 44 maddeyle asıl uyguma için hazır hale getirilmiştir.

Verilerin Toplanması: Araştırmanin ön pilot ve asıl uygulamasına geçilmeden önce Hacettepe Üniversitesi'inden 28/12/2020 tarih ve E35853172-300-00001376850 sayılı etik kurul onay izni alınmıştır. Ölçek formu katılımcılara bizzat araştırmacılar tarafından ulaştırılmaya çalışılmıştır. Ancak ölçek soruları COVID-19 nedeniyle ulaşılmakta zorluk çekilen ya da ulaşılamayan öğrencilere öğretmenlerin iletişim araçlarıyla kurdukları gruplar yardımıyla doldurtulmuştur. Öğrencilere araştırmanın gönüllülük esasına dayandığı ve verilen yanıtların hiçbir şekilde bilimsel amaçlar dışında kullanılmayacağı bilgisi verilmiştir. Bunu yanı sıra öğrencilere istedikleri vakit araştırmadan ayrılabilecekleri belirtilerek ölçek sorularına samimi cevaplar vermeleri sağlanmıştır.

Verilerin Analizi: Ölçeğin AFA ve DFA analizlerden önce ölçek verilerinin normal dağılım gösterip göstermediği incelenmiştir. Bu çerçevede uç değerlerin saptanmasında $z$ puanları ve Mahalanobis uzaklıkları ölçüt alınmıştır. $Z$ değeri -3 ve +3 aralığı dışında olan veiler ile .01 manidarlık düzeyinde ki-kare $\left(x^{2}\right)$ tablo değerinin üzerindeki değerler uç değer olarak kabul edilerek veri setinden çıkartılmıştır. Böylece AFA çalışma grubu için 492 kişilik veri seti, DFA çalışma grubu için 436 kişilik veri seti $\mathrm{z}$ standart puanlarına ve Mahalanobis uzaklıklarına bakılmıştır. AFA çalışma grubunda $(n=7)$, DFA çalışma grubunda ( $n=10)$ kişiye ait veriler -3 ve +3 aralığ 1 dışında ve Mahalanobis uzaklıkları uygun olmadığından uç değer olarak kabul edilmiş ve veri setinden çıkarılmıştır. Böylece AFA için 485 öğrenciden; DFA için 426 öğrenciden elde edilen veriler analize uygun görülmüştür.

Ölçekteki kayıp değerler EM algoritması (Beklenti-maksimizasyon algoritmas1/Expectation-maximization algorithm) seri ortalaması alınarak giderilmiştir. Ölçeğin Kurtosis (basıklık) ve Skewness (çarpıklık) değerleri ise sırasıyla 1.692 ve -1.127 olarak bulgulanmıştır. Kurtosis 
(basıklık) ve Skewness (çarpıklık) değerlerinin -2 ve +2 arasında değişmesi verilerin normal dağılım gösterdiğine işaret etmektedir (Field, 2009; Kalaycl, 2010). Bu nedenle araştırma verilerinin normal dağılım gösterdiği anlaşıldıktan sonra açımlayıcı faktör analizinde varimax dik döndürme yöntemi ve temel bileşenler analizi, doğrulayıcı faktör analizinde ise maksimum olabilirlik analizinin uygulanmasına karar verilmiştir. Ölçeğin güvenirliği için Cronbach's Alpha iç tutarlılık katsayısı ve Spearman Brown iki yarı güvenirlik katsayısı hesaplanmış olup tüm geçerlik ve güvenirlik analizleri SPSS 24.00 ve LISREL 8.80 istatiksel paket programları kullanılarak bulgulanmıştır.

\section{Bulgular}

Bu kısım ölçeğin açımlayıcı faktör analizi (AFA) bulguları, doğrulayıcı faktör analizi (DFA) bulguları ve güvenirlik analizi bulguları alt başlıklarından oluşmaktadır.

Ölçeğin Açımlayıcı Faktör Analizi (AFA) Bulguları: Vatandaşlık algısı ölçeğinin (VAÖ) faktör yapısını belirlemek amacıyla açımlayıcı faktör analizi (AFA) yapılmıştır. AFA çalışma grubundan elde edilen verilerin faktör analizine uygunluğunu test etmek amaciyla Kaiser-Meyer-Olkin (KMO) ve Barlett testleri yapılmıştır. VAÖ için yapılan analiz sonucunda KMO değeri .95 ve Barlett Küresellik testi $\left[x^{2}=5193.487\right.$; $\mathrm{sd}=378$; $\left.\mathrm{p}<.01\right]$ olarak bulunmuştur. KMO değerinin $.60^{\prime}$ dan büyük ve Bartlett testinin anlamlı çıkması, araştırma verilerinin faktör analizi için uygun olduğunu gösterir (Ntoumanis, 2001; Şencan, 2005). Başka bir anlatımla Bartlett's değerinin anlamlılı̆̆ı araştırma verilerinin çok değişkenli normal dağılımdan geldiklerini ispatlamaktadır. Verilerin analize uygun olduğunun görülmesinin ardından ölçeğin faktör yapısını ortaya koymak amaciyla faktörleştirme yöntemi olarak temel bileşenler analizi, döndürme yöntemi olarak da dik döndürme yöntemlerinden varimax (maksimum değişkenlik) seçilmiştir. Alanyazında ölçek geliştirme çalışmalarında ölçekte yer alan maddeler için madde test korelâsyonlarının .30 ve üstünde olması ve maddelerin birden fazla faktöre girmemesi önerilmektedir (Abell, Springer ve Kamata; 2009; Erkuş, 2011; Stevens, 2002; Tavşancıl, 2010). Birden fazla faktöre girme 
ile ilgili alınabilecek ölçüt maddelerin faktör yükleri arasında en az .10 fark olmasıdır. Bu bakımdan ölçek maddelerinin iki faktördeki yük değerleri arasında .10 'dan az fark olan maddeler binişik maddeler olarak adlandırılmakta ve ölçekten çıkarılmaktadır (Özdamar, 2015; Tavşancıl, 2010; Yavuz, 2005). Bununla beraber açımlayıcı faktör analizinde aynı yapıyı ölçmeyen maddelerin elenmesi, ortak faktör varyansı, madde özdeğerlerinin en az 1 olması, açıklanan varyans oranı ve ölçülmek istenen kuramsal alt yapının temsil edilebilmesi gibi kriterler de dikkate alınmaktadır (Shevlin ve Lewis, 1999; Tabachnick ve Fidell, 2013).

Araştırmanın AFA sonuçlarına göre ortak varyans değeri .30 'un altında olan 4 madde, madde faktör yükü .30'un altında olan 7 madde ve birden çok faktörde yüksek yük değeri veren binişik 5 madde ölçekten çıkarılmıştır. Gerçekleştirilen temel bileşenler analizine göre, ölçekte yer alan 28 maddenin anlam ve içerik bakımından uyumlu ve öz değeri 1'den büyük 5 alt faktör altında toplandığı görülmüştür. VAÖ'nün faktör sayısının belirlenmesinde ortaya çıkan yamaç-birikinti (Scree Plot) grafiği ise Şekil 1'de gösterilmiştir.

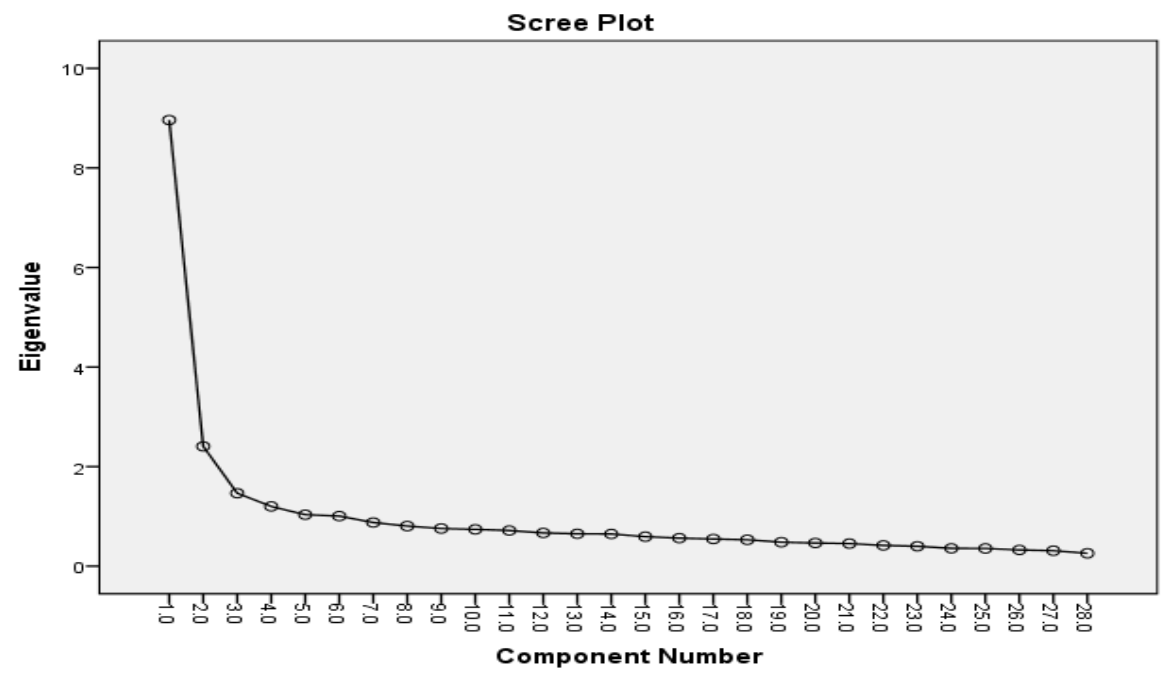

Şekil 1. VAÖ'nün yamaç-birikinti (Scree Plot) grafiği

Şekil 1'de anlaşılacağ gibi yamaç-birikinti grafiğinde Y eksenindeki bileşenler, $\mathrm{X}$ eksenine doğru bir iniş göstermektedir. Bu iniş 6 . faktörden 
itibaren önemli ölçüde kaybolmaya başlamış ve 5 önemli kırılma noktasının ortaya çıkmasını sağlamıştır. Böylece 6. kırılma noktasından sonra bileşenlerin varyansa yaptıkları katkı hem küçük, hem de neredeyse aynı düzeydedir. $\mathrm{Bu}$ nedenle ölçeğin faktör sayısının 5 olmasının uygun olacağına karar verilmiştir.

VAÖ maddelerinin faktörlere göre dağılımı, ortak varyans değeri, döndürme sonrası madde faktör yük değerleri, özdeğerler, faktörlerin açıklanan varyans değeri ve açılanan toplam varyans değerleri ise Tablo 1'de gösterilmiştir.

Tablo 1. VAÖ'nün AFA sonuçları

\begin{tabular}{|c|c|c|c|c|c|c|}
\hline Faktör & Madde & $\begin{array}{l}\text { Maddelerin } \\
\text { Ortak Varyansı }\end{array}$ & $\begin{array}{l}\text { Döndürme } \\
\text { Sonrası Madde } \\
\text { Faktör Yükleri }\end{array}$ & Özdeğerler & $\begin{array}{l}\text { Açıllanan } \\
\text { Varyans } \\
\text { Değeri (\%) }\end{array}$ & $\begin{array}{l}\text { Açıklanan } \\
\text { Toplam } \\
\text { Varyans Değeri } \\
(\%)\end{array}$ \\
\hline \multirow{5}{*}{ Faktör 1} & $\mathrm{~V} 1$ & .58 & .71 & \multirow{5}{*}{5.020} & \multirow{5}{*}{17.930} & \\
\hline & $\mathrm{V} 2$ & .51 & .63 & & & \\
\hline & V3 & .40 & .38 & & & \\
\hline & V4 & .58 & .67 & & & \\
\hline & V5 & .33 & .45 & & & \\
\hline \multirow{10}{*}{ Faktör 2} & V6 & .67 & .76 & \multirow{10}{*}{3.110} & \multirow{10}{*}{11.107} & \\
\hline & V7 & .66 & .75 & & & \\
\hline & V8 & .60 & .74 & & & \\
\hline & V9 & .31 & .40 & & & \\
\hline & V10 & .37 & .52 & & & \\
\hline & V11 & .43 & .50 & & & \\
\hline & V12 & .63 & .69 & & & \\
\hline & V13 & .61 & .61 & & & \\
\hline & V4 & .60 & .67 & & & 53820 \\
\hline & V15 & .56 & .60 & & & 53.822 \\
\hline \multirow{4}{*}{ Faktör 3} & V16 & .57 & .44 & \multirow{4}{*}{2.352} & \multirow{4}{*}{8.401} & \\
\hline & V17 & .66 & .73 & & & \\
\hline & V18 & .68 & .72 & & & \\
\hline & V19 & .52 & .52 & & & \\
\hline \multirow{5}{*}{ Faktör 4} & V20 & .62 & .50 & \multirow{5}{*}{2.303} & \multirow{5}{*}{8.224} & \\
\hline & V21 & .61 & .70 & & & \\
\hline & V22 & .53 & .65 & & & \\
\hline & V23 & .45 & .46 & & & \\
\hline & $\mathrm{V} 24$ & .44 & .32 & & & \\
\hline \multirow{4}{*}{ Faktör 5} & V25 & .59 & .75 & \multirow{4}{*}{2.285} & \multirow{4}{*}{8.161} & \\
\hline & V26 & .61 & .76 & & & \\
\hline & V27 & .48 & .67 & & & \\
\hline & $\mathrm{V} 28$ & .58 & .70 & & & \\
\hline
\end{tabular}


Tablo 1'de görüldüğ̈̈ üzere ölçekte yer alan maddeler birbirinden bağımsız 5 faktörde toplanmıştır. Maddelerin ortak varyans değerlerinin .31 ile .68; döndürme sonrası faktör yük değerlerinin .32 ile .76; faktör özdeğerlerinin 2.285 ile 5.020; açıklanan varyans değerlerinin \%8.161 ile \%17.930 arasında değiştiği bulgulanmıştır. 5 faktörün açıkladığ toplam varyans oranı ise \%53.822'dir. Sosyal bilimlerde açılanan toplam varyans değerinin çok faktörlü ölçeklerde $\% 40$ ile $\% 60$ arasında olması gerektiği belirtilmektedir (Tavşancıl, 2010). Buna göre ölçeğin \%53.822'lik açıklanan toplam varyans değeriyle yeterli olduğu söylenebilir.

VAÖ'nin AFA sonucunda 5 faktörlü ve 28 maddeden oluşan bir ölçme aracı ortaya çıkmıştır. AFA sonucunda ortaya çıkan 5 alt faktör, faktörü oluşturan maddelerin içerikleri dikkate alınıp birer boyut olarak adlandırılmıştır. Bu bağlamda VAÖ'nün 5 alt boyutu ve madde numaraları Tablo 2' de verilmiştir.

Tablo 2. VAÖ' nün alt boyutları ve madde numaraları

\begin{tabular}{|c|c|}
\hline VAÖ'nün Boyutları & Madde Numarası \\
\hline İnsan Olmak Boyutu & 1.,2.,3., 4. ve 5. sorular \\
\hline Görev ve Sorumluluk Boyutu & 6.,7.,8.,9.,10.,11.,12.,13.,14. ve 15.sorular \\
\hline Hak ve Özgürlükler Boyutu & 16.,17.,18. ve 19.sorular \\
\hline Etkin (Aktif) Vatandaşlık Boyutu & 20.,21.,22.,23. ve 24.sorular \\
\hline Birlikte Yaşama Boyutu & $25 ., 26 ., 27$. ve 28. sorular \\
\hline
\end{tabular}

VAÖ’nün cevaplama şekli “(1) Kesinlikle Katılmıyorum, Katılmiyorum, (3) Katıliyorum, (4) Kesinlikle Katılıyorum" şeklinde dörtlü likert olarak düzenlenmiştir. Ölçekte katılımcıların her bir maddeye katılma düzeyi ise "1.00-1.75: Kesinlikle katılmiyorum; 1.762.51: Katılmiyorum; 2.52-3.27: Katıliyorum; 3.28-4.00:Kesinlikle Katılıyorum" şeklindedir. Ayrıca ölçek maddelerinin puan ortalamaları "1-2.00 arasında düşük düzey katılım”; "2.01-3.00 arasında orta düzey katılım"; "3.01-4.00 arasında ise yüksek düzey katılım" olarak yorumlanabilir. Ölçeğin tersten kodlanan maddesi bulunmamaktadır. Ölçekten alınabilecek en yüksek toplam puan 112; en düşük toplam puan ise $28^{\prime}$ dir. VAÖ'den alınabilecek yüksek puanlar öğrencilerin vatandaşlık algılarının yüksek olduğunu; düşük puanlar ise öğrencilerin vatandaşlık algılarını düşük olduğunu göstermektedir. 
Ölçeğin Doğrulayıcı Faktör Analizi (DFA) Bulguları: Vatandaşlık algısı ölçeğinin (VAÖ) AFA sonucunda ortaya çıkan 5 boyutlu yapısının doğrulanıp doğrulanmadığını ortaya çıkarmak LISREL 8.80 paket bilgisayar programila birinci düzey DFA ve ikinci düzey DFA yapılmıştır. DFA, esas itibariyle bir yapısal eşitlik modelidir (YEM) ve önceden kurgulanmış ya da tasarlanmış yapının toplanan verilerle ne derece doğrulandığını tespit etmeyi amaçlar (Çokluk, Şekercioğlu ve Büyüköztürk, 2010; Lee, 2007). DFA işlemlerinde çeşitlik iyilik uyum değerleri bulunmaktadır. Bu araştırmada iyilik uyum değerlerinin eşik değerleri ve kabul edilebilir sinırları Tablo 3'te gösterilmiştir (Brown, 2014; Çokluk vd., 2010; Harrington, 2009; Hu ve Bentler, 1999; Hooper, Coughlan, ve Mullen, 2008; Kline, 2011; Meyers, Gamst ve Guarino, 2006; Munro, 2005; Şimşek, 2007; Tabachnick ve Fidell, 2013).

Tablo 3. DFA İçin İyilik Uyum İndeksleri

\begin{tabular}{lll}
\hline Uyum İyiliği Değerleri & Mükemmel Uyum & Kabul Edilebilir Uyum \\
\hline P & $>.01$ veya .05 & $<.01$ veya .05 \\
$x^{2} /$ sd & $\leq 2$ & $2-5$ \\
RMSEA & $\leq .05$ & $\leq .08$ \\
SRMR & $\leq .05$ & $\leq .08$ \\
RMR & $\leq .05$ & $\leq .08$ \\
AGFI & $\geq .90$ & $\geq .85$ \\
GFI & $\geq .90$ & $\geq .85$ \\
CFI & $\geq .95$ & $\geq .90$ \\
NFI & $\geq .95$ & $\geq .90$ \\
NNFI & $\geq .95$ & $\geq .90$ \\
IFI & $\geq .95$ & $\geq .90$ \\
RFI & $\geq .95$ & $\geq .90$ \\
PNFI & $\geq .95$ & $\geq .50$ \\
PGFI & $\geq .95$ & $\geq .50$
\end{tabular}

VAÖ'nün birinci düzey DFA ve ikinci düzey DFA'sında en çok olabilirlik yöntemi (maximum likelihood) kullanılmış ve ortaya çıkan yapıya ilişkin uyum iyilik değerleri hesaplanmıştır. Bu bağlamda VAÖ'nün birinci düzey DFA'dan elde edilen maddelerin faktör yük değerleri ve hata varyansları Şekil 2' de sunulmuştur. 


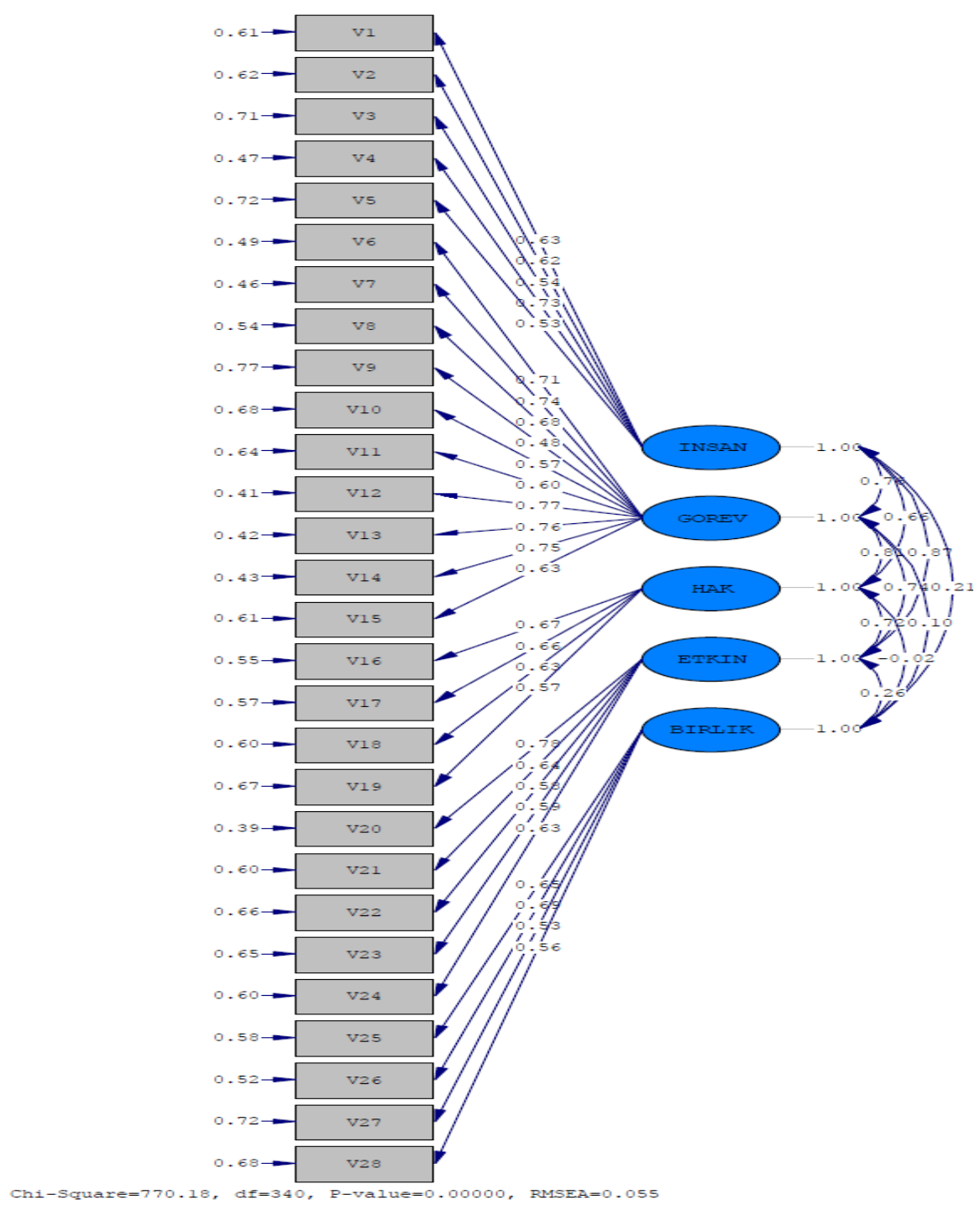

Şekil 2. VAÖ'nin birinci düzey DFA path (yol) diyagramı

Şekil 2'de görüldüğü gibi VAÖ'nün birinci düzey path (yol) diyagramında her bir maddenin örtük bağımlı değişken üzerindeki etki miktarları ve madde faktör yük değerleri görülmektedir. Maddelere 
ilişkin faktör yük değerleri insan olmak boyutunda .53 ile .73 arasında; görev ve sorumluluk boyutunda .48 ile .77 arasında; hak ve özgürlükler boyutunda .57 ile .67 arasında; etkin vatandaşlık boyutunda .58 ile .78 arasında; birlikte yaşama boyutunda ise .53 ile .69 arasında değişmektedir. Ölçeğin tümü için maddelerin faktör yüklerinin .48 ile .78; hata varyanslarının ise .39 ile .77 arasında değiştiği bulgulanmıştır. Buna göre ölçeğin madde faktör yük değerleri ve hata varyansları bakımından da uygun değerlere sahip olduğu söylenebilir. Bunun yanı sıra VAÖ'nün birinci düzey DFA sonuçlarının uyum iyilik değerleri de hesaplanmıştır. VAÖ'nün birinci düzey DFA uyum iyilik değeleri Tablo $4^{\prime}$ te verilmiştir.

Tablo 4. VAÖ'nün birinci düzey DFA uyum iyilik değerleri

\begin{tabular}{lllllccccc}
\hline Model & $\boldsymbol{x}^{2} / \mathbf{d f}$ & RMSEA & SRMR & AGFI & GFI & CFI & NFI & NNFI & IFI \\
\hline 5 Faktörlü Yap1 & 2.088 & .055 & .051 & .86 & .89 & .97 & .95 & .97 & .97 \\
\hline
\end{tabular}

Tablo 4'ten anlaşılacağı üzere VAÖ'nün birinci düzey DFA uyum iyilik değerlerinin uygun olduğu belirlenmiştir (bkz: Tablo 3 ve Tablo 4). Ayrıca VAÖ’nün birinci düzey uyum iyilik değeleri yeterli olduğundan herhangi bir modifikasyona ihtiyaç duyulmamıştır. Tablo 4 'te yer almayan uyum ölçütlerinden biri de araştırmanın örneklem yeterliğini gösteren "Kritik N (Critical N-CN)" değeridir. Bu araştırma için kritik N değeri 227.30 olarak bulunmuştur. Bu değer, araştırmada kullanılan 426 kişilik örneklemin yeterli olduğunun bir göstergesidir.

Alanyazında çok boyutlu ölçeklerin ikinci düzey DFA'sının yapılması gerektiği belirtilmektedir (Meydan ve Şeşen; 2011; Seçer, 2013). Bu nedenle VAÖ'nün ikinci düzey DFA'sı da yapılmıştır. Ölçeğe ilişkin ikinci düzey DFA'dan elde edilen maddelerin faktör yük değerleri ve hata varyansları Şekil 3'te gösterilmiştir. 


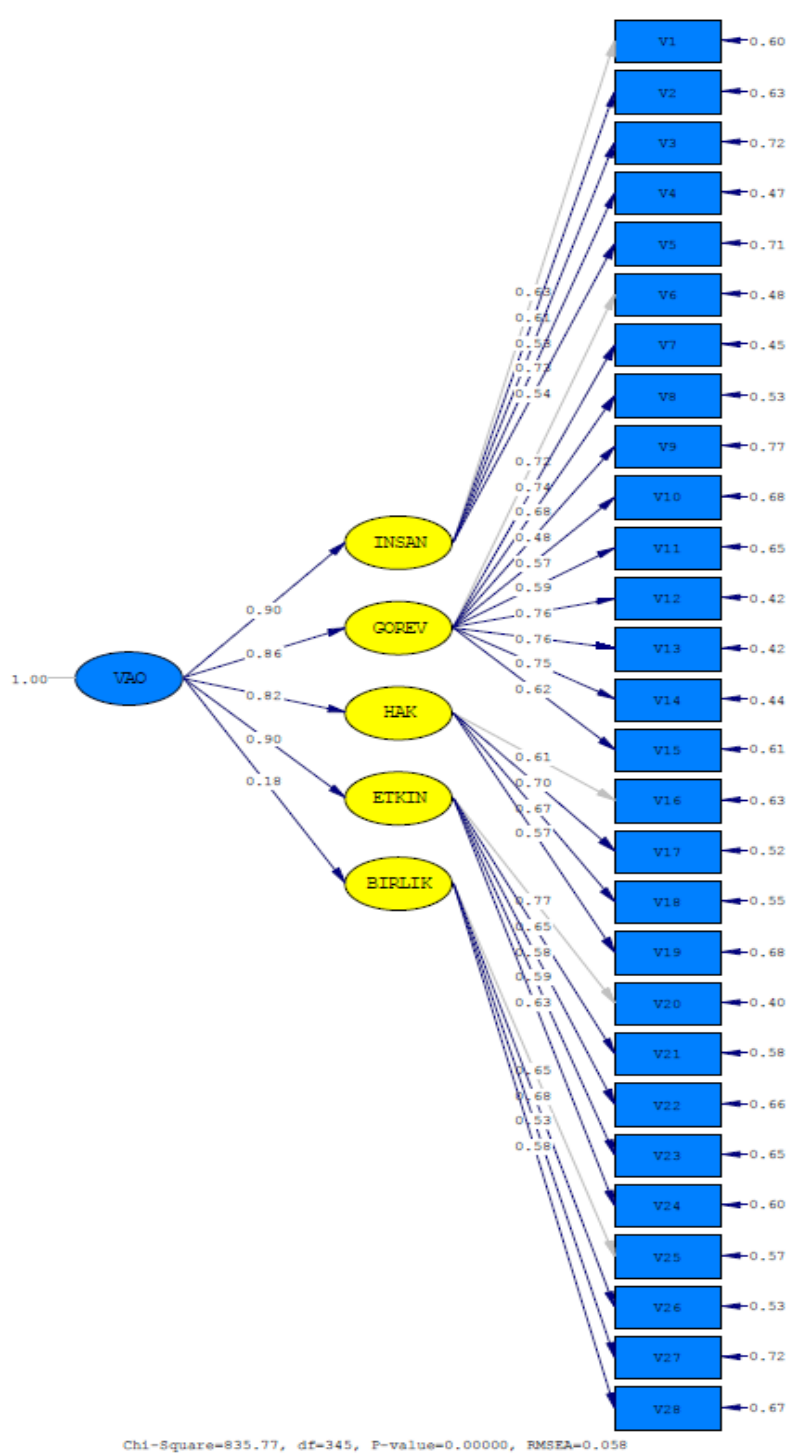

Şekil 3. VAÖ'nin ikinci düzey DFA path (yol) diyagramı

Şekil 3'te anlaşılacağı üzere VAÖ'nün ikinci düzey path (yol) diyagramında maddelere ilişkin faktör yük değerleri insan olmak boyutunda .53 ile .73 arasında; görev ve sorumluluk boyutunda .48 ile .76 arasında; hak ve özgürlükler boyutunda .57 ile .70 arasında; etkin 
vatandaşlık boyutunda .58 ile .77 arasında; birlikte yaşama boyutunda ise .53 ile .68 arasında değişmektedir. Ölçeğin tümü için maddelerin madde faktör yüklerinin .48 ile .77; hata varyanslarının ise .42 ile .77 arasında değiştiği bulgulanmıştır. Buna göre ölçeğin ikinci düzey DFA'da da madde faktör yük değerleri ve hata varyansları bakımından uygun değerlere sahip olduğu söylenebilir. Bunun yanı sıra VAÖ'nün ikinci düzey DFA sonuçlarının uyum iyilik değerleri de hesaplanmıştır. VAÖ'nün ikinci düzey DFA uyum iyilik değerleri Tablo 5'te verilmiştir.

Tablo 5. VAÖ'nün ikinci düzey DFA uyum iyilik değerleri

\begin{tabular}{lllllccccc}
\hline Model & $x^{2} / \mathbf{d f}$ & RMSEA & SRMR & AGFI & GFI & CFI & NFI & NNFI & IFI \\
\hline 5 Faktörlü Yapı & 2.422 & .058 & .057 & .86 & .88 & .97 & .95 & .97 & .97 \\
\hline
\end{tabular}

Tablo 5'ten anlaşılacağı üzere VAÖ'nün ikinci düzey DFA uyum iyilik değerlerininn de uygun olduğu belirlenmiştir (bakınız: Tablo 3 ve Tablo 5). Ayrıca VAÖ’nün ikinci düzey uyum iyilik değeleri yeterli olduğundan ikinci düzey DFA'da herhangi bir modifikasyona ihtiyaç duyulmamıştır. Tablo 5'te yer almayan uyum ölçütlerinden biri de araştırmanın örneklem yeterliğini gösteren "Kritik N (Critical N-CN)" değeridir. Bu araştırma için kritik $\mathrm{N}$ değeri 215.84 olarak bulunmuştur. $\mathrm{Bu}$ değer, araştırmada kullanılan 426 kişilik örneklemin yeterli olduğunun bir göstergesidir.

VAÖ'nün birinci düzey DFA ve ikinci düzey DAF analizlerinde yapılan standart çözümlemelerden sonra maddeler ve faktörler arasındaki $\mathrm{t}$ değerlerine bakılmıştır. $\mathrm{t}$ değerleri örtük değişkenlerin gözlenen değişkenleri açıklama oranlarına yönelik anlamlılık düzeyini ifade eder (Çolak, Yorulmaz ve Altınkurt, 2017). Ölçeğin birinci düzey DFA'da $\mathrm{t}$ değerleri 9.86 ve 18.07 arasında; ikinci düzey $\mathrm{DFA}^{\prime} \mathrm{da} \mathrm{t}$ değerleri ise 8.01 ve 15.23 arasında değişmektedir. Ölçeğin birinci ve ikinci düzey DFA'sında $t$ değerlerinin $2.58^{\prime}$ den büyük olması $t$ değerlerinin .01 düzeyinde anlamlı olduğunu göstermektedir.

Güvenirlik Analizi Bulgularn: VAÖ'nün güvenirliği madde toplam korelasyonları, Cronbach's Alpha katsayısı ve Spearman Brown iki yarı güvenirlik katsayıları hesaplanarak bulunmuştur. Tablo 6'da ölçeğin güvenirliğine ilişkin analiz sonuçları yer almaktadır. 
Tablo 6. VAÖ'nün güvenirlik analiz sonuçları

\begin{tabular}{|c|c|c|c|c|c|}
\hline Boyut & Madde & $\begin{array}{l}\text { Madde Toplam } \\
\text { Korelasyonu }\end{array}$ & $\begin{array}{l}\text { Cronbach's Alfa İç } \\
\text { Tutarlık Katsayısı }\end{array}$ & $\begin{array}{l}\text { Spearman } \\
\text { Yarı } \\
\text { Katsayısı }\end{array}$ & $\begin{array}{l}\text { Brown İki } \\
\text { Güvenirlik }\end{array}$ \\
\hline \multirow{5}{*}{ İnsan Olmak Boyutu } & V1 & .47 & \multirow{5}{*}{.73} & \multirow{5}{*}{.71} & \\
\hline & V2 & .50 & & & \\
\hline & V3 & .48 & & & \\
\hline & $\mathrm{V} 4$ & .58 & & & \\
\hline & V5 & .45 & & & \\
\hline \multirow{10}{*}{$\begin{array}{l}\text { Görev ve Sorumluluk } \\
\text { Boyutu }\end{array}$} & V6 & .60 & \multirow{10}{*}{.89} & \multirow{10}{*}{.85} & \\
\hline & V7 & .63 & & & \\
\hline & v8 & .57 & & & \\
\hline & V9 & .45 & & & \\
\hline & V10 & .52 & & & \\
\hline & V11 & .54 & & & \\
\hline & V12 & .66 & & & \\
\hline & V13 & .70 & & & \\
\hline & V14 & .66 & & & \\
\hline & V15 & .53 & & & \\
\hline \multirow{4}{*}{$\begin{array}{l}\text { Hak ve Özgürlükler } \\
\text { Boyutu }\end{array}$} & V16 & .48 & \multirow{4}{*}{.72} & \multirow{4}{*}{.75} & \\
\hline & V17 & .52 & & & \\
\hline & V18 & .50 & & & \\
\hline & V19 & .47 & & & \\
\hline \multirow{5}{*}{$\begin{array}{l}\text { Etkin(Aktif) } \\
\text { Vatandaşlık Boyutu }\end{array}$} & V20 & .66 & \multirow{5}{*}{.78} & \multirow{5}{*}{.72} & \\
\hline & V21 & .53 & & & \\
\hline & V22 & .50 & & & \\
\hline & V23 & .49 & & & \\
\hline & V24 & .48 & & & \\
\hline \multirow{4}{*}{$\begin{array}{l}\text { Birlikte } \\
\text { Boyutu }\end{array}$} & V25 & .35 & \multirow{4}{*}{.71} & \multirow{4}{*}{.73} & \\
\hline & V26 & .32 & & & \\
\hline & V27 & .31 & & & \\
\hline & V28 & .33 & & & \\
\hline \multicolumn{3}{|c|}{ Ölçeğin Tamamına İlişkin Güvenirlik Katsayısı } & .90 & .84 & \\
\hline
\end{tabular}

Tablo 6'da görüldüğü gibi VAÖ' nün madde toplam korelasyon değerleri .31 ile .70 arasında değişmektedir. Madde toplam korelasyonu .30 ve daha yüksek olması ölçek maddelerinin bireyleri iyi derecede ayırt ettiğini ifade eder (Seçer, 2013). Bununla birlikte ölçeğin güvenirliği için Cronbach's Alfa iç tutarlık katsayıları ve Sperman Brown iki yarı güvenirlik katsayıları da incelenmiştir. VAÖ' nün Cronbach's Alpha iç tutarlılık katsayıları ile Sperman Brown iki yarı güvenirlik katsayıları ölçeğin tüm alt boyutlarında ve tamamında .70'in üzerindedir. Ölçme araçlarının güvenirlik katsayısının .70 ve daha yüksek olması verilerin güvenilirliği bakımından yeterli olduğu (Fraenkel, Wallen ve Hyun, 2012; Liu, 2003) göz önünde bulundurulduğunda ölçeğin güvenilir bir 
ölçek olduğu sonucuna ulaşılabilir. Ayrıca VAÖ'nün iç geçerlik kapsamında alt \% 27 ve üst \% 27 gruplarının madde ortalama puanları arasındaki farklar bağımsız örneklem $t$ testi ile incelenmiştir. VAÖ'nün iç geçerliğine yönelik analiz sonuçları Tablo 7'de verilmiştir.

Tablo 7. VAÖ'nün alt \%27 ve üst \%27'lik gruplar için bağımsız örneklem $t$ testi sonuçları

\begin{tabular}{|c|c|c|}
\hline \multirow[b]{2}{*}{ Madde Numarası } & \multicolumn{2}{|c|}{ Alt \%27 ve Üst \%27 } \\
\hline & $t$ değerleri & $p$ \\
\hline V1 & -9.185 & $.00^{*}$ \\
\hline V2 & -10.475 & $.00^{*}$ \\
\hline V3 & -10.970 & $.00^{*}$ \\
\hline V4 & -11.553 & $.00^{*}$ \\
\hline V5 & -10.812 & $.00^{\circ}$ \\
\hline V6 & -13.680 & $.00^{*}$ \\
\hline V7 & -13.228 & $.00^{*}$ \\
\hline V8 & -13.057 & $.00^{*}$ \\
\hline V9 & -12.796 & $.00^{*}$ \\
\hline V10 & -12.538 & $.00^{*}$ \\
\hline V11 & -12.264 & $.00^{*}$ \\
\hline V12 & -16.462 & $.00^{*}$ \\
\hline V13 & -14.708 & $.00^{*}$ \\
\hline V14 & -14.340 & $.00^{*}$ \\
\hline V15 & -12.228 & $.00^{*}$ \\
\hline V16 & -13.321 & $.00^{*}$ \\
\hline V17 & -12.548 & $.00^{*}$ \\
\hline V18 & -11.367 & $.00^{*}$ \\
\hline V19 & -11.941 & $.00^{*}$ \\
\hline V20 & -14.406 & $.00^{*}$ \\
\hline V21 & -12.351 & $.00^{*}$ \\
\hline V22 & -11.440 & $.00^{*}$ \\
\hline V23 & -10.401 & $.00^{*}$ \\
\hline V24 & -12.086 & $.00^{*}$ \\
\hline V25 & -7.215 & $.00^{*}$ \\
\hline V26 & -6.337 & $.00^{*}$ \\
\hline V27 & -3.275 & $.00^{*}$ \\
\hline V28 & -7.718 & $.00^{*}$ \\
\hline
\end{tabular}

Tablo 7'den anlaşılacağı üzere VAÖ'nün tüm maddeleri için $t$ değerleri $p=.001$ düzeyinde anlamlıdır. Buna göre VAÖ maddelerinin iç geçerliklerinin yüksek olduğu ve maddelerin ayırt edici olduğu söylenebilir. Araştırmanın tüm geçerlik ve güvenirlik sonuçları birlikte değerlendirildiğinde "Vatandaşlık Algısı Ölçeğinin (VAÖ)” psikometrik 
açıdan öğrencilerin vatandaşlık algılarını ölçebilecek uygun bir ölçme aracı olarak kullanılabileceği söylenebilir.

\section{Tartışma, Sonuç ve Öneriler}

$\mathrm{Bu}$ araştırma, öğrencilerin vatandaşlık algılarını ölçebilecek geçerli ve güvenilir bir ölçme aracı geliştirmeyi amaçlamaktadır. Araştırma sonuçları "insan olmak, görev ve sorumluluk, hak ve özgürlükler, etkin (aktif) vatandaşlık ve birlikte yaşama" boyutlarından oluşan ölçeğin öğrencilerin vatandaşlık algılarını ölçebilecek geçerli ve güvenilir bir ölçme aracı olduğuna işaret etmektedir.

Vatandaşlık algısı ölçeğinin (VAÖ) boyutları ve maddeleri Milli Eğitim Bakanlığı'nın Sosyal Bilgiler, İnsan Hakları, Vatandaşlık ve Demokrasi dersleri öğretim programındaki "insan olmak (her insan değerlidir), görev ve sorumluluk, hak ve özgürlükler, etkin (aktif) vatandaşlık, birlikte yaşama (çeşitliliğe çoğulcu bakış)" temaları göz önünde bulundurulmuştur (Altay vd., 2019; Tüysüz, 2019; Tüzün, 2019). Ölçeğin madde havuzu oluşturma sürecinde ilgili yurt içi (Bingöl, 2000; Çolak, 2015; Demirbaş, 2016; Durmuş, 2017; Durualp ve Doğan, 2017; Ersoy, 2012; İçen, 2017; İçen, Öztürk ve Yılmaz, 2017; Öcal, 2011; Özbek, 2004; Tonga, 2013; Utku, 2015) ve yurt dişı alanyazınından (Dinesen, Norgaard ve Klemmensen, 2014; Evans, 2006; Groot, 2011; Hahn, 2015; Kennedy, 2007; Kuang ve Kenedy, 2014; Marshall, 2005; O'Brien ve Smith, 2011; Losito ve D'Amira, 2003; Sears ve Hughes, 1996; Schulz, Ainley, Fraillon, Kerr ve Losito, 2009; Torney-Purta, Lehmann, Oswald ve Schulz, 1999; Zhang, 2011) yararlanılmıştır.

68 ifadeden oluşan ölçek madde havuzu, kapsam geçerliğ i bakımından 3'ü eğitim yönetimi, 2'si ölçme ve değerlendirme alanından olmak üzere toplam 5 uzman kişinin görüşüne sunulmuştur. Uzmanlardan gelen dönütler ve öneriler doğrultusunda VAÖ'nün maddeleri bir kez daha gözden geçirilmiş ve gerekli düzenlemeler yapılmıştır. Bu çerçevede madde havuzundan toplam 18 madde çıkartılarak ön uygulamaya hazır 50 maddelik bir ölçek elde edilmiştir. VAÖ, Siirt il merkezinde ortaöğretim (lise) kurumlarında öğrenim görev 84 öğrenciye ön pilot çalışma olarak uygulanmıştır. Ön pilot uygulama sonucunda ölçek, 44 maddeyle asıl uyguma için hazır hale getirilmiştir. 
Araştırmada iki örneklem grubundan yararlanılmıştır. AFA ve DFA için 300 kişilik veya ölçek maddelerinin en az beş katı kadar katılımcı sayısı olmasina (Comrey ve Lee, 1992; Tabachnick ve Fidell, 2013) dikkat edilmiştir. AFA için 485 öğrenciye; DFA için 426 öğrenciye ulaşılmış olması örneklem sayısının yeterli olduğu anlamına gelmektedir. Ayrıca ölçeğin Kurtosis (basıklık) ve Skewness (çarpıklık) değerlerinin -2 ve +2 değerleri arasında olması ve normal dağılım göstermesi nedeniyle (Field, 2009; Kalayc1, 2010) açımlayıcı faktör analizinde varimax dik döndürme yöntemi ve temel bileşenler analizi, doğrulayıcı faktör analizinde ise maksimum olabilirlik analizinin uygulanmasına karar verilmiştir.

AFA çalışma grubundan elde edilen verilerin faktör analizine uygunluğunu test etmek amaciyla Kaiser-Meyer-Olkin (KMO) ve Barlett testleri yapılmıştır. VAÖ için yapılan analiz sonucunda KMO değeri .95 ve Barlett Küresellik testi $\left[x^{2}=5193.487 ; \mathrm{sd}=378 ; \mathrm{p}<.01\right]$ olarak bulunmuştur. KMO ve Barlett Küresellik testi bulguları, verilerin çok değişkenli normal dağılım gösterdiklerinin bir kanıtı olarak yorumlanabilir. AFA işlemleri aynı yapıyı ölçmeyen maddelerin elenmesi, ortak faktör varyansı, madde özdeğerlerinin en az 1 olması, açıklanan varyans oranı ve ölçülmek istenen kuramsal alt yapının temsil edilebilmesi ölçütlerine göre (Shevlin ve Lewis, 1999; Tabachnick ve Fidell, 2013) yapılmıştır. Bu ölçütler doğrultusunda ölçekte yer alan maddeler birbirinden bağımsız 5 faktörde toplanmıştır. Maddelerin ortak varyans değerlerinin .31 ile .68; döndürme sonrası faktör yük değerlerinin .32 ile .76; faktör özdeğerlerinin 2.285 ile 5.020; açıklanan varyans değerlerinin \%8.161 ile \%17.930 arasında değiştiği bulgulanmıştır. 5 faktörün açıkladığı toplam varyans oranı ise \%53.822' dir. Sosyal bilimlerde açklanan toplam varyans değerinin çok faktörlü ölçeklerde $\% 40$ ile $\% 60$ arasında olması gerektiği belirtilmektedir (Tavşancıl, 2010). Dolayısıyla ölçeğin \%53.822'lik açıklanan toplam varyans değeri açısından yeterli olduğu söylenebilir. Ölçeğin tersten kodlanan maddesi bulunmamaktadır. 4'lü likert tipine göre ölçekten alınabilecek en yüksek toplam puan 112; en düşük toplam puan ise $28^{\prime}$ dir. VAÖ'den alınabilecek yüksek puanlar öğrencilerin vatandaşlık algılarının yüksek olduğunu; düşük puanların ise öğrencilerin vatandaşlık algılarının düşük olduğunu ifade etmektedir. 
Vatandaşlık algısı ölçeğinin AFA sonucunda ortaya çıkan 5 boyutlu yapısının doğrulanıp doğrulanmadığını ortaya çıkarmak birinci düzey DFA ve ikinci düzey DFA yapılmıştır. Birinci düzey DFA $\left(x^{2} / \mathrm{df}=2.088\right.$, RMSEA $=.055$, SRMR $=. .051$, AGFI $=.86, \mathrm{GFI}=.89, \mathrm{CFI}=.89, \mathrm{NFI}=.95$, $\mathrm{NNFI}=.97, \mathrm{IFI}=.97)$ ikinci düzey DFA $\left(x^{2} / \mathrm{df}=2.422, \mathrm{RMSEA}=.058\right.$, $\mathrm{SRMR}=.057, \mathrm{AGFI}=.86, \mathrm{GFI}=.88, \mathrm{CFI}=.97, \mathrm{NFI}=.95, \mathrm{NNFI}=.97, \mathrm{IFI}=.97$ ) sonuçları araştırma verilerinin ölçeğin faktöryel yapısıyla uyum gösterdiği şeklinde açıklanabilir. Bunun yanı sıra ölçeğin güvenirliğgi için Cronbach's Alfa iç tutarlık katsayıları ve Sperman Brown iki yarı güvenirlik katsayıları da incelenmiştir. VAÖ’ nün Cronbach's Alpha iç tutarlılık katsayıları ile Sperman Brown iki yarı güvenirlik katsayıları ölçeğin tüm alt boyutlarında ve tamamında .70'in üzerinde olduğu tespit edilmiştir. Ölçme araçlarının güvenirlik katsayısının .70 ve daha yüksek olması verilerin güvenilirliği bakımından yeterli olduğu (Fraenkel, Wallen ve Hyun, 2012; Liu, 2003) anlamına gelmektedir. Araştırmanın tüm geçerlik ve güvenirlik sonuçları birlikte değerlendirildiğinde “Vatandaşlık Algısı Ölçeğinin (VAÖ)” psikometrik açıdan öğrencilerin vatandaşlık algılarını ölçebilecek uygun bir ölçme aracı olarak kullanılabileceği söylenebilir.

Araştırma bir ölçek geliştirme çalışması olarak farklı örneklem gruplarıyla test edilebilir veya farklı örneklem gruplarına uyarlanabilir. "Duyuşsal vatandaşlık ve davranışsal vatandaşlık" boyutlarından oluşan yeni vatandaşlık algısı ölçeği geliştirilebilir. Bununla birlikte ölçeğin güvenirliğinin test-tekrar test yöntemine göre de yapılması önerilebilir. 
EXTENDED ABSTRACT

\title{
Validity and Reliability Study of the Citizenship Perception Scale
}

\author{
* \\ Mehmet Sabir Çevik- Şefika Şule Erçetin \\ Hacettepe University
}

Education systems aim to raise individuals who can fulfill their civic duties in changing conditions and who have truly embraced citizenship (Öztürk and Deveci, 2011). Especially, considering the effective citizenship skills and citizenship values that students should have as one of the basic citizenship competencies (Özden, 2011) serves the purpose in question. Indeed, in domestic (Bingöl, 2000; Durualp and Doğan, 2017; İçen, 2017; İçen, Öztürk and Yılmaz, 2017; Öcal, 2011; Özbek, 2004; Utku, 2015) and international literature (Dinesen, Norgaard and Klemmensen, 2014; Kennedy, 2007; Kuang and Kenedy, 2014; Marshall, 2005; O'Brien and Smith, 2011; Schulz, Ainley, Fraillon, Kerr and Losito, 2009; Zhang, 2011) discussing the concept of citizenship with various aspects and the existence of numerous studies measuring the citizenship perceptions of students can be considered as an indicator of the importance given to citizenship. On the other hand, in the literature, some studies on citizenship have also been conducted in the form of a scale development study (Durualp and Doğan, 2017; İçen, Öztürk, andYılmaz, 2017; Morais and Ogden, 2011; Utku, 2015; Uydaş, 2014). However, the mentioned scale development studies on citizenship do not measure students' perception of citizenship as a whole or they concentrate on only one dimension of citizenship. For this reason, developing measurement tools that can measure students' perceptions of citizenship in integrity can fill the gap in the literature and contribute to the literature. Besides, it is hoped that an up-to-date and new measurement tool to be developed for citizenship perception will shed light on better understanding of students' citizenship perceptions.

It is only possible to determine the level of citizenship perception in students, the direction in which students' perception of citizenship intensifies, and whether students have the desired perception of 
citizenship only with valid and reliable measurement tools.In addition to this, the development of a valid and reliable measurement tool can contribute to the prediction of citizenship behaviors in students by determining the citizenship perceptions of the students. Accordingly, the current research aims to develop a valid and reliable measurement tool that can measure students' perception of citizenship.

In the process of creating the item pool of the scale, related domestic literature (Bingöl, 2000; Durualp and Doğan, 2017; İçen, 2017; İçen, Öztürk and Y1lmaz, 2017; Öcal, 2011; Özbek, 2004; Utku, 2015) and international literature (Dinesen, Norgaard andKlemmensen, 2014; Kennedy, 2007; Kuang and Kenedy, 2014; Marshall, 2005; O'Brien and Smith, 2011; Schulz, Ainley, Fraillon, Kerr andLosito, 2009; Zhang, 2011) were used. In line with the feedback and suggestions from the experts, the articles of CPS were reviewed once again and the necessary arrangements were made.In this framework, a total of 18 items were removed from the item pool and a 50-item scale ready for preapplication was obtained.

Two sample groups were used in the study. 485 students for EFA; 426 students were reached for CFA. It was decided to apply the varimax vertical rotation method and principal component analysis in the exploratory factor analysis, and the maximum likelihood analysis in the confirmatory factor analysis.Kaiser-Meyer-Olkin (KMO) and Barlett tests were conducted to test whether the data obtained from the EFA study group compatiblewith factor analysis.As a result of the analysis for CPS, it was found that KMO value was .95 and Barlett's Sphericity test was [ $\mathrm{x} 2$ $=5193.487 ; \mathrm{sd}=378 ; \mathrm{p}<.01]$.As a result of EFA, the items in the scale were collected in 5 independent factors. It was found that the common variance values of the items were between .31 and .68; After rotation, factor load values were between .32 and .76; factor eigenvalues were between 2.285 and 5.020; and the variance values explained varied between $8.161 \%$ and $17.930 \%$. The total variance rate explained by 5 factors was $53.822 \%$.The scale has no items coded in reverse.The highest total score that can be obtained from the scale according to the 4-point Likert type is 112; the lowest total score is 28 . High scores that can be obtained from CPS indicate that students' perception of citizenship is high; low scores indicate that students' perception of citizenship is low. 
First level CFA was performed to find out whether the 5-dimensional structure of the citizenship perception scale, which emerged as a result of EFA, was confirmed.The first level CFA results $\left(\mathrm{x}^{2} / \mathrm{df}=2.088\right.$, RMSEA $=$ $.055, \mathrm{SRMR}=. .051, \mathrm{AGFI}=.86, \mathrm{GFI}=.89, \mathrm{CFI}=.89, \mathrm{NFI}=.95, \mathrm{NNFI}=.97, \mathrm{IFI}=$ .97) can be explained as the research data are compatible with the factorial structure of the scale.In addition, Cronbach's Alpha internal consistency coefficients and Sperman Brown split half reliability coefficients were also examined for the reliability of the scale. Cronbach's Alpha internal consistency coefficients and Sperman Brown split half reliability coefficients of CPS were found to be above .70 in all subdimensions of the scale.When all the validity and reliability results of the study are evaluated together, it can be said that the "Citizenship Perception Scale (CPS)" can be used as an appropriate measurement tool that can measure students' perception of citizenship psychometrically.

\section{Kaynakça/References}

Abell, N., Springer, D. W. and Kamata, A. (2009). Developing and validating rapid assessment instruments. New York: Oxford University Press.

Altay, N., Ay, S., Ertek, Z. Ö., Polat, H., Selmanoğlu, E. and Yalçın, H. (2019). İnsan Hakları ve Demokrasi. Ankara: Cem Web Ofset A.Ş.

Arslan, S. (2014). Çokkültürlü toplumlarda vatandaşlı eğitimine yönelik öğretmen ve öğrenci düşüncelerinin incelenmesi (Yayımlanmamış Doktora Tezi). Marmara Üniversitesi, Eğitim Bilimleri Enstitüsü, İstanbul.

Aybay, R. and Özbek, N. (2015). Vatandaşlık hukuku. İstanbul: Bilgi Üniversitesi Yayınları.

Battery, M. (2003). The end of citizenship? The nation state, threats to its legimacy and citizenship education in the twenty first century. Cambridge Journal of Education, 33(1), 101-102.

Biesta, G. (2014). Learning in public places: Civic learning for the twenty-first century. Biesta, G., De Bie, M., and Wildemeersch, D. (Eds.). Civic learning, democratic citizenship and the public sphere (p.1-14). Newyork: Springer.

Bingöl, D. (2000). Demokratik tutum ve değerler açısından üniversite gençliği. İktisadi ve İdari Blimler Dergisi, 14(1), 129-157.

Blaug, R. and Schwarzmantel, J. (2016). Democracy: A reader (2nd ed.). Newyork: Columbia University Press. 
Brown, T. A. (2014). Confirmatory factor analysis for applied research. New York: Guilford Publications.

Comrey, A. L. and Lee, H. L. (1992). A first course in factor analysis. Hillsdale, New Jersey: Erlbaum.

Çokluk, Ö., Şekercioğlu, G. and Büyüköztürk, Ş. (2010). Sosyal bilimler için çok değişkenli istatistik: SPSS ve LISREL uygulamaları. Ankara: Pegem Akademi Yayıncilik.

Çolak, İ., Yorulmaz, Y. İ. and Altınkurt, Y. (2017). Öğretmen özyeterlik inancı ölçeği geçerlik ve güvenirlik çalışması. Muğla Sıtkı Koçman Üniversitesi Eğitim Fakültesi Dergisi, 4(1), 20-32.

Çolak, K. (2015). Sosyal bilgiler ile vatandaşlık ve demokrasi eğitimi derslerinde küresel vatandaşlı eğitimi. (Yayımlanmamış doktora tezi). Marmara Üniversitesi, Eğitim Bilimleri Enstitüsü, İstanbul.

Demir, Ö. and Acar, M. (2005). Sosyal bilimler sözlüğü. Ankara: Adres Yayınevi. Demirbaş, İ. (2016). Üniversite öğrencilerinin vatandaşlık algısının belirlenmesi. (Yayımlanmamış yüksek lisans tezi). Kastamonu Üniversitesi Sosyal Bilgiler Enstitüsü, Kastamonu.

Dinesen, P. T., Norgaard, A. S. and Klemmensen, R. (2014). The civic personality: Personality and democratic citizenship. Political Studies, 62(1), 134-152.

Durmuş, G. (2017). Sosyal bilgiler öğretmen adaylarının küresel vatandaşlık ve çokkültürlü eğitime yönelik tutumlarının incelenmesi (Yayımlanmamış yüksek lisans tezi). Amasya Üniversitesi, Sosyal Bilimler Enstitüsü, Amasya.

Durualp, E. and Doğan, İ. (2017). Vatandaşlık algısı ölçeğinin faktör yapısının incelenmesi. The Journal of Academic Social Science Studies, 62, 65-83.

Edge, D. and Copp, G. (2000). Young people and changing 1dentities/citizenship in Europe: Citizens ' $\mathrm{R}$ ' Us?. A. Ross. (Ed). Proceedings of the Second Conference of the Children's Identity and Citizenship in Europe Thematic Network- Athens (p.217-222). London: CiCe Publication.

Erçetin, Ş. Ş. and Açıkalın, Ş. N. (2020). Bilimsel araştırmalarda temel yaklaşımlar, araştırma modelleri ve desenleri. (Edt.: Ş. Ş. Erçetin). Araştırma teknikleri (p.29-49). Ankara: Nobel Yayıncllık.

Erdem, F. H. (2012). Osmanl1-Türkiye anayasalarında ve yeni anayasada vatandaşlik. Seta analiz, 51, 1-23. 
Erkuş, A. (2011). Çok boyutlu lider-izleyici etkileşiminde kişilik özelliklerinin ve güç kaynaklarının rolü. Atatürk Üniversitesi İktisadi ve İdari Bilimler Dergisi, 25(1), 127-152.

Ersoy, A. F. (2007). Sosyal bilgiler dersinde öğretmenlerin etkili vatandaşlı eğitimi uygulamalarına ılişkin görüşleri. (Yayımlanmamış doktora tezi). Anadolu Üniversitesi Eğitim Bilimleri Enstitüsü, Eskişehir.

Ersoy, A. F. (2012). Annelerin vatandaşlık algısı, çocuklarında vatandaşlık bilinci geliştirme uygulamaları ve karşılaştıkları sorunlar. Kuram ve Uygulamada Eğitim Bilimleri, 12(3), 2111-2124.

Esen, H. (2011). Sosyal bilgiler öğretim programındaki insan hakları ve vatandaşlık bilinci ile ilgili konularm öğretmen görüşlerine göre belirlenmesi (Yayımlanmamış yüksek lisans tezi). 18 Mart Üniversitesi, Sosyal Bilimler Enstitüsü, Çanakkale.

Evans, M. (2006). Educating for Citizenship: What teachers say and what teachers do. Canadian Journal of Education, Democracy and Education, 29(2), 410-435.

Fay, B. (2017). Çă̆daş sosyal bilimler felsefesi:çokkültürlü bir yaklaşım (Çev.: İ. Türkmen). İstanbul: Ayrıntı Yayınları.

Field, A. (2009). Discovering statistics using SPSS for windows. London: Sage Publications.

Flowers, N. (2000). The human rights education handbook: Effective practices for learning, action, and change. Minnesota: Human Rights Resource Center.

Fraenkel, J. R., Wallen, N. E. and Hyun, H. H. (2012). How to design and evaluate research in education. New York: McGraw Hill.

Golubeva, I. (2018). The links between education and active citizenship/civic engagement. NESET II Ad Hoc Report No 1/2018.https://nesetweb.eu/wop-content/uploads/2019/06/_NESET2 AHQ1.pdf (Erişim Tarihi: 14.12.2019).

Groot, I. (2011). Why we are not democratic yet: the complexity of developing a democratic attitude. In Veugelers, W. (Ed.), Education and humanism: linking autonomy and humanity. (p.79-93). Rotterdam: Sense Publishers.

Gündüz, M. and Gündüz, F. (2007). Yurttaşlık bilinci. Ankara: Anı Yayıncılık.

Hahn, C. L. (2015). Teachers' perceptions of education for democratic citizenship in schools with transnational youth: A comparative study in the UK and Denmark. Research in Comparative and International Education, 10(1), 95-119. 
Harrington, D. (2009). Confirmatory factor analysis. Oxford: Oxford University Press.

Hooper, D., Coughlan, J. and Mullen, M. (2008). Structural equation modelling: Guidelines for determining model fit. Electronic Journal of Business Research Methods, 6(1), 53-60.

Hu, L. and Bentler, P. M. (1999). Cutoff criteria for fit indexes in covariance structure analysis: Conventional criteria versus new alternatives. Structural Equation Modeling: A Multidisciplinary Journal, 6(1), 1-55.

İbrahimoğlu, Z. (2014). Gayri müslim azınlıklara göre Türkiye'de vatandaşlık ve vatandaşlı eğitimi. (Yayımlanmamış doktora tezi). Marmara Üniversitesi, Eğitim Bilimleri Enstitüsü, İstanbul.

İçen, M. (2017). Dezavantajlı bölgelerdeki lise öğrencilerinin vatandaşlık algısı. (Yayımlanmamış doktora tezi). Marmara Üniversitesi, Eğitim Bilimleri Enstitüsü, İstanbul.

İçen, M., Öztürk, C. and Yılmaz, A. (2017). Vatandaşlık duygusu ölçeği güvenirlik ve geçerlik çalışması. International Journal of Field Education, 3(2), 26-36.

İpek, İ. (2011). Ilköğretim 6. ve 7. sinıf sosyal bilgiler ders kitaplarmda vatandaşlı eğitiminin sosyal bilgiler öğretim programındaki hedeflere uygunluk yönünden değerlendirilmesi. (Yayımlanmamış Yüksek Lisans Tezi). Balıkesir Üniversitesi, Sosyal Bilimler Enstitüsü, Balıkesir.

Kalaycı, Ş. (2010). Faktör analizi. (Edt.: Ş. Kalaycı). SPSS uygulamalı çok değişkenli istatistik teknikleri, Ankara: Asil Yayın Dağıtım.

Karasar, N. (2014). Bilimsel araştırma yöntemi. Ankara: Nobel Yayıncılık.

Kartal, F. (2002). Liberal and republican conceptualizations of citizenship: A theoretical inquiry. Turkish Public Administration Annual, 27-28, 101130.

Kaya, B. (2013). Sosyal bilgiler öğretmen adaylarının vatandaşlı algıları ile politik ilgi ve katıllmları arasındaki ilişkinin incelenmesi. (Yayımlanmamış doktora tezi). Marmara Üniversitesi, Eğitim Bilimleri Enstitüsü, İstanbul.

Kennedy, K. J. (2007). Student constructions of 'active citizenship': What does participation mean to students? British Journal of Educational Studies, 55(3), 304-324.

Kline, R. B. (2011). Principles and practice of structural equation modeling. New York: The Guilford Press. 
Kuang, X. and Kennedy, K. J. (2014). Assian students' perceptions of 'good' citizenship: The role of democratic values and attidues to traditional culture. Asia Pacific Journal of Educational Development, 3(1), 33-42.

Lee, S. Y. (2007). Structural equation modeling. New Jersy: John Wiley and Sons Ltd.

Liu (2003). Developing a scale to measure the interactivity of websites. Journal of Advertising Research, June, 207-217.

Losito, B. and D'Amira, A. (2003). Democracy, citizenship, participation. The results of the second rea civic education study in Italy. International. Journal of Education Research, 39(6), 609-620.

Marshall, T. H. and Bottomore, T. (2000). Yurttaşlık ve toplumsal sinıflar (Çev.: A. Kaya). Ankara: Gündoğan Yayınları.

Marshall, H. (2005). Developing the global gaze in ctizenship education; exploring the perspectives of global education ngo workers in England. International Journal of Citizenship and Teacher Education, 1(2), 76-91.

Marshall, T. H. (2016). Class, citizenship and social development. In Blaug, R., and Schwarzmantel, R. (Eds.), Democracy: $A$ reader (2nd ed.). Newyork: Columbia University Press.

Meydan, C. H. ve Şeşen, H. (2011). Yapısal eşitlik modellemesi AMOS uygulamaları. Ankara: Detay Yayıncilik.

Meyers, L. S., Gamst, G. and Guarino, A. J. (2006). Applied multivariate research: Design and interpretation. London: Sage.

Morais, B. D. and Ogden, C. A. (2011) Initial development and validation of the global citizenship scale. Journal of Studies in International Education, 15(5), $445-466$.

Munro, B. H. (2005). Statistical methods for health care research. Newyork: Lippincott Williams and Wilkins.

Ntoumanis, N. (2001). A step-by-step guide to SPSS for sport and exercise studies. New York: Routledge.

O'Brien, J. L. and Smith J. M. (2011). Elementary education students' perceptions of "good" citizenship. Journal of Social Studies Education Research, 2(1), 21-36.

Onyx, J., Kenny, S. and Brown, K. (2012). Active citizenship: An empirical investigation. Social Policy and Society, 11(1), 55-66. 
Osler, A. and Starkey, H. (2003). Learning for cosmopolitan citizenship: Theoretical debates and young people's experiences. Educational Review, 55(3), 243-254.

Öcal, A. (2011). İlköğretim yedinci sınıf öğrencilerinin vatandaşlık hakları konusundaki görüşleri. Elektronik Sosyal Bilimler Dergisi, 10(35), 134149.

Özbek, R. (2004). Vatandaşlık ve insan hakları eğitimi ders amaçlarının gerçekleşme düzeyi (Yayımlanmamış doktora tezi). Atatürk Üniversitesi, Sosyal Bilimler Enstitüsü, Erzurum.

Özdamar, K. (2015). Ölçek ve test geliştirme yapısal eşitlik modellemesi. Ankara: Nisan Kitabevi.

Özden M. (2011). 4. ve 5. sinflar fen ve teknoloji dersinin vatandaşlı eğitimi bakımından işlevselliği (Yayımlanmamış doktora tezi). Anadolu Üniversitesi, Sosyal Bilimleri Enstitüsü, Eskişehir.

Öztürk, C. ve Deveci, H. (2011). Farklı ülkelerin sosyal bilgiler öğretim programlarının değerlendirilmesi. C. ÖZTÜRK içinde, Farklı ülkelerin sosyal bilgiler öğretim programları. Ankara: Pegem Akademi Yayıncllık.

Pamuk, A. (2007). Avrupa vatandaşlı̆̆1 ve eğitim. Ulusal teknik eğitim, mühendislik ve eğitim bilimleri genç araştırmacılar sempozyumu. Kocaeli (20-22 Haziran), 957-961.

Parekh, B. (2002). Çok kültürlülü̈̆̈̈ yeniden düşünmek. (Çev.: B. Tanrıseven). Ankara: Phoenix Yayınları.

Ross, A. (2012). Editorial: Education for active citizenship: Practices, policies and promises. International Journal of Progressive Education, 8(3), 7-14.

Sağırlı, M. (2005). Bir konu alanı olarak vatandaşlık bilgisi. E. T. Temiz (Ed.), Vatandaşlik bilgisi (s.9-25). İstanbul: Lisans Yayıncilık.

Schugurensky, D. (2005). Citizenship and citizenship education: Canada in an international context. Ontario Institute for Studies in Education. 1wqtxts1 xzle7. cloudfront. net/ $31416546 /$ DS_Contexts_of_citizenship_ ed_2006. pdf ?1371618583=and response-content-disposition=inline $\% 3 B$ (E.Tarihi: 02.10.2020).

Schulz, W., Ainley, J., Fraillon, J., Kerr, D. and Losito, B. (2009). ICCS international report: civic knowledge, attitudes and engagement among lowersecondary school students in 38 countries. Amsterdam: International Association for the Evaluation of Educational Achievement.

Sears, A. M. and Hughes, A. S. (1996). Citizenship education and current educational reform. Canadian Journal of Education, 21(2), 123-142. 
Seçer, İ. (2013). SPSS ve LISREL ile pratik veri analizi. Ankara: Anı Yayıncılık.

Shevlin, M. E. and Lewis, C. A. (1999). The revised social anxiety scale: Exploratory and confirmatory factor analysis. The journal of social psychology, 2, 250-252.

Stevens, J. P. (2002). Applied multivariate statistics for the social sciences. (Fourth Edition). New Jersey: Lawrance Erlbaum Association, Inc.

Şahin, K. (2012). Türkiye'de sosyal bilgiler dersi müfredatındaki yurttaşlık eğitiminin avrupa birlĭgi yurttaşlı e ĕgitimi politikaları bă̆laminda değerlendirilmesi (2005-2011). (Yayımlanmamış yüksek lisans tezi). Atatürk Üniversitesi, Eğitim Bilimleri Enstitüsü, Erzurum.

Şencan, H. (2005). Sosyal ve davranışsal ölçümlerde güvenirlik ve geçerlilik. Ankara: SeçkinYayıncilık.

Şimşek Ö. F. (2007). Yapısal eşitlik modellemesine giriş: Temel ilkeler ve LISREL uygulamaları. Ankara: Ekinoks Yayınları.

Tabachnick, B. G. and Fidell, L. S. (2013). Using multivariate statistics. Boston, Pearson.

Tavşancıl, E. (2010). Tutumların ölçülmesi ve SPSS ile veri analizi. Ankara: Nobel Yayın Dağıtım.

Tonga, D. (2013). 8. sınıf öğrencilerinin vatandaşlık bilinci düzeylerinin çeşitli değişkenler açısından değerlendirilmesi (Yayımlanmamış doktora tezi). Gazi Üniversitesi, Eğitim Bilimleri Enstitüsü, Ankara.

Torney Purta, J., Lehmann, R., Oswald, H. and Schulz, W. (1999). Citizenship and education in twenty-eight countries: Civic knowledge and engagement at age fourteen. Amsterdam: İnternational Association for the Evaluation of Educational Achievement.

Tüysüz, S. (2019). Sosyal bilgiler ders kitabı 4. Ankara: Tuna Matbaacılık San. ve Tic. A.Ş.

Tüzün, G. (2019). Demokrasi ve insan hakları. Ankara: Ada Matbaacilık Yayıncllık Sanayi ve Ticaret Ltd. Şti.

Utku, M. (2015). Üniversite öğrencilerinin vatandaşlık ve sosyal medya (sosyal ă̆) vatandaşlık algısının çeşitli değişkenlere göre incelenmesi. (Yayımlanmamış yüksek lisans tezi). Erzincan Üniversitesi, Sosyal Bilimler Enstitüsü, Erzincan.

Uydaş, İ. (2014). Ortä̈ğretim öğrencilerinin küresel vatandaşlık bağlamında çokkültürlülük hakkındaki görüşlerinin değerlendirilmesi (Çanakkale ili örneği). (Yayımlanmamış yüksek lisans tezi). Çanakkale Onsekiz Mart Üniversitesi, Eğitim Bilimleri Enstitüsü, Çanakkale. 
Waltzer, K. and E. Heilman (2005). When Going Right is Going Wrong. Education for Critical Democratic Patriotism. The Social Studies, 156162.

Westheimer, J. (2015). What kind of citizen? educating our children for the common good. New York: Teachers College Press.

Wildemeersch, D. (2014). Displacing concepts of social learning and democratic citizenship. In Biesta, G., De Bie, M., and Wildemeersch, D. (Eds.), Civic Learning, Democratic Citizenship and the Public Sphere (p.15-28). Newyork: Springer.

Yavuz, S. (2005). Developing a technology attitude scale for pre-service chemistry teachers. The Turkish Online Journal of Educational Technology, 4(1), 17-25.

Yeşil, R. (2002). Okul ve ailede insan hakları ve demokrasi eğitimi. Ankara: Nobel Yayınları.

Yurtseven, G. (2006). Vatandaşlık. Ankara: Nobel Yayın Dağıtım.

Zhang, Y. (2011). Citizenship education in china: comparing eighth grade students' civic attitudes and civic engagement in shangai and Hong Kong. (Unpublished doctoral dissertation). Minnesota Üniversitesi, USA.

\section{Kaynakça Bilgisi / Citation Information}

Çevik, M. S. ve Erçetin, Ş. Ş. (2021). Vatandaşlık Algısı Ölçeği'nin geçerlik ve güvenirlik çalışması. OPUS- Uluslararası Toplum Araştırmaları Dergisi, 18(43), 6445-6477. DOI: 10.26466/opus.938404. 